\title{
Bringing Feedback and Resilience of High-latitude Ecosystems into the Corporate Boardroom
}

\section{Whiteman, G.}

Royal Swedish Academy of Sciences

2004

Whiteman, G. et al. 2004. Bringing Feedback and Resilience of High-latitude Ecosystems into the Corporate Boardroom. Ambio 33(6): 371-376.

http://hdl.handle.net/1975/271

Downloaded from Helda, University of Helsinki institutional repository.

This is an electronic reprint of the original article.

This reprint may differ from the original in pagination and typographic detail.

Please cite the original version. 


\section{Bringing Feedback and Resilience of High-latitude Ecosystems into the Corporate Boardroom}

This paper discusses the role of companies in high-latitude regions, which are conceptualized as socially and economically mediated ecosystems, and identifies a number of important social actors within the business environment. We present three examples of corporate activity at high latitudes and discuss a variety of common threads. Notably, we argue that business theory and practice needs to move beyond a narrow social or economic concept of organizational resilience and embrace the ecological resilience of high-latitude regions as a business management goal. We also suggest that regional ecosystem resilience needs to become a meaningful measure of sustainable corporate governance, one that corporate boards of directors can review and commit to. The paper concludes with a call for a detailed research agenda on the role of transnational and national companies within high-latitude regions.

\section{INTRODUCTION}

In February 2003, British Petroleum (BP) agreed to pay 6.75 billion USD for a $50 \%$ stake in what will be the third largest Russian oil producer (1). On 16 May 2003 Royal Dutch/Shell announced a 10 USD billion investment in Sakhalin II in eastern Russian - making it the biggest oil and gas project in the world (2). Such development is not new. Arctic and boreal regions have been subject to externally driven economic development for well over a hundred years, with the North American Gold Rush in the 1890 s as an early example. However, large-scale development by transnational and national corporations is becoming increasingly common in these ecosystems. At the same time, the high latitude regions are showing increasing ecological and social vulnerability (3). In this paper, we argue for the need to study the role of companies in the dynamics of ecosystem change in order to better understand the vulnerability of high-latitude regions.

First, we discuss the role of companies in high-latitude regions, which are conceptualized as socially and economically mediated ecosystems, and identify a number of other important social actors within the business environment. Then we present three examples of corporate activity at high latitudes and discuss a variety of common threads. Notably, we argue for the need for business theory and practice to move beyond a social or economic concept of organizational resilience and embrace the ecological resilience of high-latitude regions as a business management goal. We also suggest that regional ecosystem resilience needs to become a meaningful measure of sustainable corporate governance, one that corporate boards of directors can review and commit to. Finally, we conclude with a call for a detailed research agenda on the role of transnational and national companies within high-latitude regions.

\section{HIGH-LATITUDE REGIONS AS SOCIALLY AND ECONOMICALLY MEDIATED ECOSYSTEMS}

The sustainability of high-latitude ecosystems depends upon their degree of resilience. According to Folke et al. (4) resilience of social-ecological systems is related to $i$ ) the magnitude of shock that the system can absorb and remain within a given state, ii) the degree to which the system is capable of self-organization, and iii) the degree to which the system can build capacity for learning and adaptation. From an ecological perspective, resilience is concerned with the long-term capacity of an ecosystem to rejuvenate itself (5).

The sustainability of high-latitude ecosystems is impacted by ecological, social, and economic systems at local, regional and global scales (Fig. 1). The business environment interconnects these systems and provides important feedbacks that affect the long-term functioning of high-latitude regions (6). In systems thinking, a positive feedback amplifies the change in input, pushing the system towards greater change, whereas a negative feedback counteracts this and helps to maintain the status quo (7). Positive feedbacks can lead to upward spirals of change (e.g. greater and greater profit) or downward spirals of change (e.g. fewer and fewer ecological resources). However, increasing profit at the expense of ecological resources may not necessarily be a trade-off; some companies and busi-

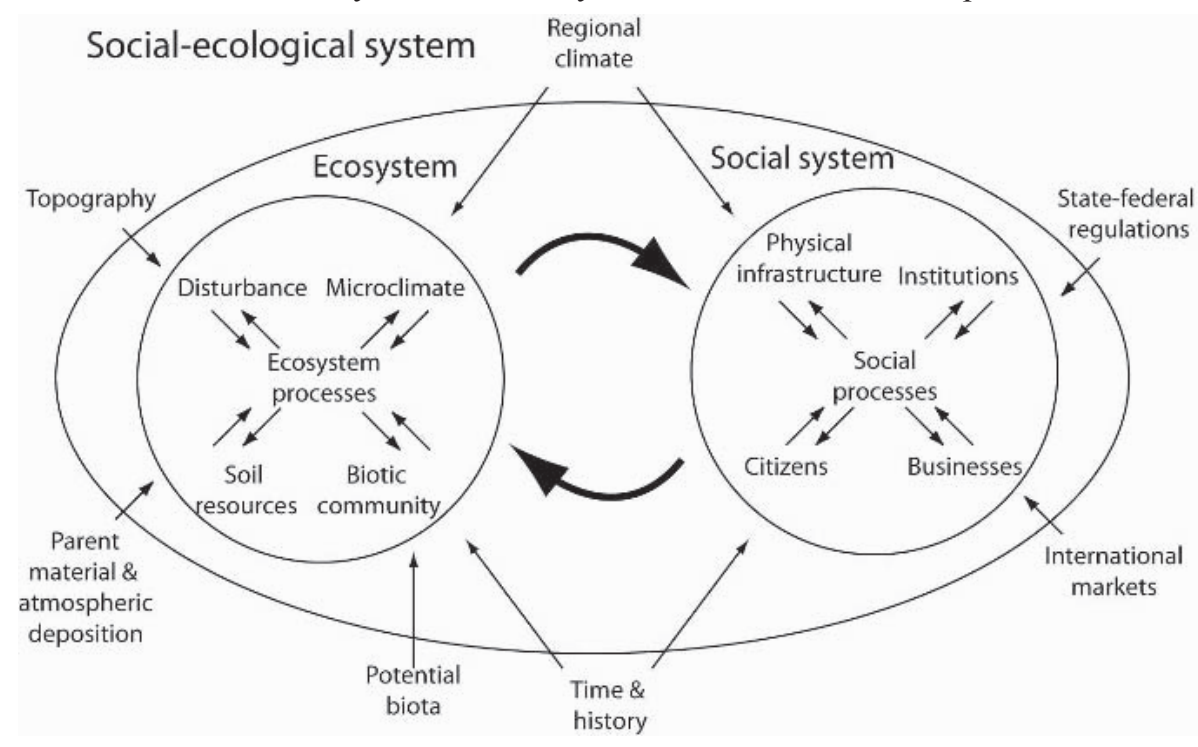

Figure 1. A social-ecological system consists of ecological and social subsystems that strongly influence one another at local and regional scales. For each subsystem there are strongly influence one another at local and regional scales. For each subsystem there are
external factors (e.g. regional climate and international markets) that are not influenced by local conditions (known as state factors by ecologists) and internal factors (e.g. institutions or disturbances), which respond to external factors and which both affect, and are affected by local processes (known as interactive controls by ecologists) (adapted from 4). 
ness academics believe that growth in shareholder value and ecological sustainability can occur simultaneously (8). Social and economic processes create webs of positive and negative feedbacks that may be structurally similar to, or different from, those of ecological systems (6). Whereas ecological feedbacks have a strong physical basis, business feedbacks are socially and economically mediated and are somewhat less predictable. A business environment can thus create and respond to positive and negative feedback loops in an economic, social and ecological sense (6).

The pressure to develop high-latitude regions continues as social and economic feedbacks in other parts of the globe demand more products and services. These economic links exert strong pressure on high-latitude ecosystems but are largely decoupled from specific locations. From a corporate perspective, high latitudes house valuable natural resources such as oil and gas, hydro-electricity, forest products, minerals and metals, fisheries, and increasingly act as a site for tourism. Infrastructure development-ports, pipelines, roads, airports, shipping routes - used to facilitate economic development plans, carries additional economic opportunities and potential ecological costs. Multinational companies and their governmental counterparts in many countries continue to eye high-latitude resources as a bounty waiting to be exploited. In addition to the direct impact of companies operating within the geographical boundaries of high-latitude regions, companies indirectly impact the system through activities at lower latitudes, such as $\mathrm{CO}_{2}$ emissions that contribute to global climate change, and by creating suitable conditions and environments for invasive species, which in turn may negatively affect the native biota.

Changes in high-latitude ecosystems have immediate implications for companies functioning in the north. For example, global warming has begun to interfere with efforts to discover more oil in Alaska (9). Cod in the North Sea is nearly extinct, which directly affects the viability of the European fishing industry. Exxon is still feeling the negative effects from the Alaska oil spill, and a federal court ruled that the company "cannot return to the Alaska sound it fouled 13 years ago with nearly 11 million gallons of crude." (10). On the other hand, climate change can present new business opportunities in highlatitude regions. For example, decreasing sea ice may result in the opening up the Northwest Passage between the Atlantic and Pacific Oceans, as well as the Northern Sea Route in the Russian Arctic, which creates new opportunities for transportation and for oil and gas exploration and development, while at the same time creating additional stress on the ecological resilience of such systems (11).

From a systems perspective, companies are active managers that create and react to positive and negative feedback loops within their business system. Most business strategies are designed to generate positive feedback loops that enhance corporate advantages (e.g. investment in advertising to create more demand, which increases profits; investment in infrastructure to produce more products, which increases income). This behavior creates additional feedback loops that connect business activities to ecological systems. Unless companies notice and constructively manage these linkages, the resulting malfunctioning or incomplete feedbacks between the social, economic and ecological systems can reduce regional resilience. Folke et al. (4) suggest that "[m]anagement can destroy or build resilience, depending on how the social-ecological system organizes itself in response to management actions." Management practices that focus on flexibility and adaptive learning can help build system resilience (12).

Some companies have begun to recognize the importance of ecosystem sustainability and have initiated changes in business behavior toward the environment. However, a more common response to external social pressure for sustainability has been to manage the perceptions and actions of the broader social and economic system through advertising and public relations and thus reduce the threat of positive social feedback, rather than to address the ecological feedbacks directly. For instance, the continuing demand by international capital markets for increasing profits tends to create a positive economic feedback that creates an upward spiral for companies, yet may simultaneously generate a positive feedback leading to a downward spiral in the availability of ecological resources that are the basis of this profit. Similarly, the recent massive power blackout along the eastern seaboard of the USA and Canada - where up to 50 million people lost power-provided new 'social and economic' feedback to proponents of oil drilling in the Arctic National Wildlife Refuge (ANWR), in which consumer demand for energy led to public support for oil drilling in the ANWR, which could augment energy use. If drilling in the ANWR were to proceed, the resulting environmental impacts could generate additional social-ecological feedback loops that were not a component of the original corporate strategy.

\section{OTHER FACTORS AFFECTING HIGH-LATITUDE RESILIENCE}

Several other groups influence high-latitude ecological resilience via their role within the business environment. We briefly identify the importance of some of these actors.

Governments and regional bodies like the European Union play a critical role in maintaining the sustainability of high-latitude ecosystems and regulating the impact of companies on these areas through positive and negative feedback. For instance, the European Union has a "Northern Dimension Action Plan" (13), which comprises the external and cross-border policies of the European Union covering the Baltic Sea region, Arctic Sea region and North West Russia. It facilitates trade and economic relations particularly in energy, transportation and telecommunications, while at the same time seeking to minimize pollution or other side effects of unsustainable development.

Such governmental and regional directives can facilitate feedbacks that have either positive or negative effects on ecosystems. For example, by promoting unrestricted development in this region, they create a positive feedback in which companies are encouraged to extract resources as cheaply as possible without considering the long-term environmental consequences. This positive feedback loop leads to a progressively degraded environment. Alternatively, they can promote a negative feedback that stabilizes long-term development of the region by linking environmental performance of firms already active in the region with opportunities for continued development.

International financing institutions can also influence feedbacks because they provide much of the needed financing for corporate activities, particularly in emerging economies like Russia. Export credit agencies and banks from many countries are actively encouraging economic development in high-latitude regions. For example, the European Bank of Reconstruction and Development (EBRD), the European Investment Bank, the Nordic Investment Bank, and the World Bank (along with the European Commission, the Russian Federation, the Danish, Finnish, and Swedish governments) are collaborators in the Northern Dimension Environmental Partnership (NDEP) which supports projects in water, wastewater, solid waste, energy efficiency and nuclear waste management (14). International capital markets can also help curb high-latitude investment through pressure from ethical investor groups, such 
as Henderson Global Investors, or from the Dow Jones Sustainability Index, which rank companies on their social and environmental performance.

Consumers have a key role to play in both demanding that companies behave more sustainably, and conversely in demanding more opportunities for consumption. On the one hand, consumers who support the Greenpeace/Friends of the Earth boycott against Exxon Mobil for its role in sabotaging international action on climate change (15), generate a negative feedback that constrains and stabilizes business dynamics, which in turn generate additional negative feedbacks to ensure ecosystem sustainability. On the other hand, consumers continue to demand greater energy resources - a positive business feedback that negatively affects the environment.

The important roles that civil society plays in high-latitude sustainability provide a mixture of feedbacks, depending upon the group or level of analysis. For instance, the agreement between the Grand Council of the Crees and Hydro-Québec on the proposed Eastmain hydroelectric project created a positive feedback that made it more likely that indigenous people would support the project since the agreement provides the Cree with CAD 3.5 billion USD (USD 2.27 billion) over 50 years (16-18). However, there was a significant portion of the local Cree population $(31 \%)$ and several NGOs that opposed the project, leading to a negative feedback that may reduce the likelihood that the project will proceed.
Accountability and monitoring allow past performance to be evaluated; if it meets the goals of the corporation, the strategy is supported; if it is unsuccessful, the strategy is changed. Policymaking seeks to project this behavior into the future. The net effect is to stabilize corporate behavior to pursue the stated goals. Strategy formation seeks to promote a positive feedback that enhances corporate advantage.

Both boards and HSECs could be useful governance mechanisms to help companies monitor and plan for regional ecosystem resilience. Boards and committees rely upon performance indicators to measure past and present orientation and also upon predictive targets to help shape future plans. Typically, these measures are financial in nature, but some progressive companies also prepare environmental and social reports. However, few (if any) measures of corporate environmental and social performance integrate measures of social-ecological resilience. Nevertheless, if indicators of resilience did enter the boardroom, then one can imagine a board or HSEC committee reviewing past and present corporate performance in terms of regional social-ecological resilience. From a future orientation, boards could help set targets for resilience (and also help set appropriate management thresholds), and could ensure that plans and formal corporate policies on regional resilience are established. Yet the 'denatured' corporate perspective on resilience often results in a distorted approach to governance, which is not ecologically embedded (16) in a concrete sense.

\section{HIGH-LATITUDE RESILIENCE AND BUSINESS THEORY}

There are at least two avenues to help bring a deeper understanding of high-latitude sustainability into corporate boardrooms: i) through an expanded concept of organizational resilience that includes measures of regional ecosystem resilience; and ii) through corporate governance mechanisms.

Resilience is a concept that is well recognized in the corporate world. The concept typically refers to the social or economic resilience of corporate employees, of organizational teams, specific companies, and/or industries in the face of social or economic stress or vulnerability $(19,20)$. This quote from Lord Browne, the $\mathrm{CEO}$ of $\mathrm{BP}$, provides a typical example of this perspective: "Stepping back I think we can best explain our strategy as a determination to have the best position for growth in an industry which is showing that it has great resilience even in volatile economic times." (21). In the wake of 9/11, American business scholars have increasingly focused on the need for leadership resilience in the face of external socio-political (terrorist) crisis (22). This approach to organizational resilience renders it a 'denatured' concept (23) that largely ignores feedbacks to ecological components of the system (for exceptions, 12, 24). The fact that resilience is an integral part of corporate strategies suggests, however, that the concept could be expanded to include ecological dimensions without a complete shift in corporate paradigm.

Corporations are formally governed and controlled by their boards of directors. Boards typically represent shareholder interests, but stakeholder interests are increasingly entering the boardroom (25). Board responsibilities can be distinguished by conformance $v s$. performance roles and also by outward $v s$ inward-looking roles (25) (Fig. 2). Inside the corporation, other committees can also have useful governance functions, such as Health, Safety, and Environment Committees (HSECs). These can be viewed as a mixture of positive and negative feedbacks.

\section{Exploring the Role of Companies in the Resilience of High- latitude Ecosystems: Three Cases}

In this section, we present three examples of transnational and large national companies that are currently impacting high-latitude regions.

\section{Case 1: Forest Industry in Finland}

In Finland, as in many other boreal countries, forests and forestry are an important source of economic wealth. Thus, forests have long been a battlefield for a variety of interests, but conflicts between conservationists and those emphasizing economic output from forests (e.g. forest industry) have intensified during recent decades. The developments leading to the situation, and consequent changes in forestry practices, have three interlinked components: i) forestry operations have intensified; ii) recreational needs have increased; and iii) the environmental movement has developed and gained strength. Thus, during the past decades forests have become objects of an increasing number of interests and interest groups with different and clashing views about forest management.

The effort to enhance economic growth is often seen as the principal cause of the intensification of forestry. Intensive and efficient forest management yield better economic returns and lead to increased living standards, and thus increased demand for recreational use of forests. On the other hand, the same for- 
estry that produced more economic growth and thereby wealth, has been perceived to cause deterioration of the forest environment. Consequently, the environmental movement has gained strength. Thus, forest conflicts are intimately linked with social development in industrialized countries during the past decades, with such phenomena as urbanization, continued industrialization, and increased standard of living leading to changed values among people.

Interestingly, some Finnish researchers claim that forest-related conflicts were partly caused - or at least aggravated-by the inability of forest industry and other forestry professionals to adapt their views and approaches to accommodate changes in the society. The previous criticism towards forest management had focused on biological issues (such as the biological effects of herbicide and pesticide use, and acid rain) and on economic and technological issues. Therefore, forestry professionals did not have the tools to cope with the new type of criticism that dealt with values, social issues, recreational demands, and the new concept of biodiversity. The new situation led to confusion among forestry professionals and consequently an inability to find a common strategy to deal with the new criticisms (26). Significant changes in this state of affairs have taken place in the Finnish forest management procedures during the past decade.

One of the pressures contributing to changes in the northern boreal forest sector is the so-called 'market pressure', i.e. consumers demanding changes in forest management by selecting the most environmentally friendly products. There are contradictory views about whether market pressure is exerted by ordinary consumers demanding wood products from forests treated with environmentally friendly logging methods or is market pressure created by vocal and strong environmental groups acting as representatives of consumers. Nevertheless, environmental groups are one of the drivers of changes in boreal forest management, for instance, by influencing buyer companies of wood-based products and thereby forcing the producers to change forestry methods.

An illustrative example of the significance of market pressure and environmental groups is the declaration of the large German publishing house Axel Springer Verlag which sets strict environmental standards for their paper suppliers. These six Forestry Standards for the suppliers have been in force since 1995 (27):

i) Sustainability: Harvesting more timber than will re-grow is prohibited.

ii) Biodiversity: Forestry shall not endanger animal or plant species.

iii) Control: The paper manufacturer as a purchaser of timber must perform eco-controls.

iv) Training: The paper manufacturer must ensure that the necessary ecological knowledge is made available to personnel (for example, forest workers).

v) Indigenous population: The paper manufacturer must take the indigenous people (for example, the Saami in Northern Scandinavia) into consideration.

vi) Information: The paper manufacturer must keep the public informed of the advances made in environmental protection, but also of the problems encountered.

Case 2: Oil Companies and Resilience of Russian High-latitude Regions

The Russian Arctic, including its seabed, may well become one of the main sources of oil in the $21^{\text {st }}$ century. The decreasing oil resources of the North Sea may last for only another 25 years, so Europe may soon be importing up to $85 \%$ of its energy supplies. At present, Russia provides only about $20 \%$ of Europe's natural gas needs and $16 \%$ of its oil. In general, Russia faces enormous transport problems in getting its petroleum resources, much of it deep in Siberia, to export markets. This makes scenarios for shipping oil to North America profitable only at times of high prices. At present, most of Russia's oil and gas goes to Europe. In the short term, U.S. oil companies could raise Russia's oil output further by investing more there. To date, however, U.S. and multinational companies have been reluctant to invest there because of shifting tax codes and regulatory policies and have called for binding legislation before investing more money in the country. Specifically, they have been unwilling to do this without the production-sharing agreements that Russia's Duma has been reluctant to grant foreign firms (28).

Western companies began exploring projects in Russia even before the collapse of the Soviet Union, but more than a decade later they can point to few successes after combined investments of more than USD 5 billion. For example, Shell, the world's second largest oil firm, signed a memorandum at the end of the 1990s to develop oil and gas condensate deposits at Gazprom's huge Zapolyarnoye gas field in Western Siberia, but the deal was never finalized. BP, the world's third largest oil firm, has had extensive projects in the Russian north via its 50\% interest in Tyumen Oil (TNK), which produces 1.2 million barrels per day (bpd) and has reserves of 5.2 billion bbl. At the end of June 2003, U.K. Prime Minister Blair and Russian President Putin jointly announced the creation of a new oil company, TNK-BP, which will lead to a further investment of more than USD 6 billion by BP in Russia.

As the world's No. 2 oil exporter, Russia is seeking new markets outside Europe, while the U.S., the world's largest oil consumer, wants to cut its reliance on the oil-rich but volatile Middle East. Under this scenario, Murmansk-Russia's only ice-free arctic port - would become the main port for oil export to the U.S. By 2010, Russian companies hope to cover 10-15\% of crude oil consumption in the U.S. Indeed, in November 2002 Presidents Bush and Putin pledged to strengthen energy ties between their two countries. The project is part of a blossoming relationship between the former Cold War rivals. However, Washington wants more than simply increased Russian oil imports out of its new energy relationship with Moscow. It is also keen to open Russia's vast oil reserves to U.S. investors. One reason why big Western companies are prepared to risk a return to Russia is the price of oil. Diving to USD 10 a barrel in 1998, it has climbed steadily thereafter and, despite a downward dip after the terrorist strikes of September 11, has recently been buoyed by tensions in the Middle East.

In general, ecosystem degradation from petroleum extraction has been more extensive in the Russian Arctic than in North American developments. Part of the reason is that many of the largest oil and gas fields were first identified and tapped during Soviet times. Those original fields were developed recklessly with little or no concern for the technical longevity of the fields or the environmental damage resulting from exploration and exploitation. It is certain that Russia will need foreign expertise in both extraction and environmental mitigation, in addition to capital investments, to develop new fields in the Arctic. The recent merger of BP with TNK raises some hope for mitigation as its new Russian fields are developed. In the 1990s, Gazprom, and other Russian companies began selling shares on the international stock market. Most have poor records of environmental and cultural protection. Therefore, long-term multinational investment has at least the potential to be beneficial, if international standards and protocols for mitigation are instituted and adhered to. 


\section{Case 3: Beyond Petroleum}

The UK-based BP is one of the world's largest oil and gas producers and also has significant investments in alternative energy, such as solar power. BP impacts high-latitude ecosystems both through its direct role in oil and gas production in areas such as Alaska and Russia, and indirectly through its overall contribution to climate change. In 1997, BP was the first petroleum company to publicly accept the need for the precautionary principle with respect to climate change. BP also reports significant reductions in emissions and makes a commitment to maintain this performance (29).

Recently, BP has repositioned itself as a company that is "Beyond Petroleum," and launched a new marketing campaign, entitled "BP on the street," developed by award-winning advertising agency Ogilvy and Mather Worldwide. BP's advertising campaign takes a 'reality TV' approach by interviewing real people about their views on oil companies, energy needs, alternative fuels, etc. and positions BP as moving towards sustainability while acknowledging that it is only starting to make a difference.

Critics point out that the 2-year campaign cost USD 200 million, which was the same amount that BP invested in renewable technologies over a 6-year period $(30,31)$. Thus, BP is investing as much in its sustainable image as it is in sustainable technology and activity. Fortune, a key business magazine, offered this comment on the heavy use of marketing spin: "Well, please: If the world's second largest oil company is beyond petroleum, FORTUNE is beyond words" (32).

Since 2000, BP has been involved with the Global Reporting Initiative (GRI), the main global initiative to develop sustainable reporting measures based on sustainability indicators and principles that enhance accountability, particularly completeness, clarity, relevance, transparency and auditability. BP also prepares location reports, environmental performance by site and case studies (33). However, none of these localized efforts effectively bring in measures or predictions of regional resilience, such as regional economic stability in the face of fluctuating oil prices or ecological recovery (rather than degradation) after oil development. BP's Statistical Review of World Energy (34), an interactive web-based tool that helps viewers chart energy consumption and production, has the ability to chart data by nation. However, the data are not available by eco-regions, such as high-latitude areas, a missed opportunity to assess negative feedbacks that enhance regional sustainability.

\section{DISCUSSION}

Measures of high latitude ecosystem resilience (1) suggest that current and future stresses on these ecosystems may result in a severe loss of system resilience which may lead to alternative, undesired states in which the ecosystem differs fundamentally from its original state $(35,36)$. Our case studies illustrate that companies are important actors that create and react to feedback that affects high-latitude regions.

The Finnish forestry case effectively demonstrates the power of social and economic (market) feedback (via supplier codes) in promoting increased sustainability in high-latitude ecosystems. The feedback has resulted in changes aimed at more ecologically sustainable forestry practices in Finland and in other boreal and high-latitude countries. This example clearly shows that consumers have a pivotal role to play in demanding that companies behave more sustainably.

Oil development in Russia also demonstrates the importance of social and economic feedback, but with mixed results. On the one hand, foreign multinationals like Shell and BP may bring improved environmental management practices that can improve ecosystem functioning. On the other, economic and political (social) feedback from the Russian government de-emphasizes the importance of managing for ecosystem sustainability.

The last case, on Beyond Petroleum, highlights the ability of companies to create powerful social feedback via advertising. What is not clear is the degree of substance behind the public relations exercise (37). BP's marketing approach can be described in the context of feedbacks. First, the campaign is designed as a positive social and economic feedback intended to change business behavior: more ecologically minded consumers lead to more ecologically minded corporations, which lead to more ecologically minded consumers, etc. If successful, this could initiate a positive feedback for social-ecological change in which reduced corporate energy consumption reduces the projected aerial extent of oil development, which reduces costs and adds customers, which causes more corporations to engage in this behavior. However, the multi-million dollar campaign may also do much to socially mediate BP's corporate reputation, and thus reduce social pressure for change - i.e. the public relations message may act as negative social feedback and help the company resist further change.

While companies may be increasingly aware of the need to manage ecosystems and to pay attention to environmental indicators, such as the GRI, such actions may not be sustainable if ecosystem resilience has not been integrated into a company's culture and formal governance mechanism. That is, despite good intentions, companies may operate with a distorted or limited understanding of effective ecosystem resilience. While flexibility and learning is key (12), further efforts at new learning, across companies and industries, must be made. For instance, the forestry standards identified for Axel Springer Verlag are a good start, but the forest industry could be more proactive by emphasizing their ongoing commitment to sustainable forestry and more specifically, regional resilience. The examples set by proactive forest companies and companies like BP could encourage and 'force' other companies to follow suit if social and economic expectations (among consumers, civil society, governments and international financing institutions) shift towards regional resilience and sustainability. However, one of the difficulties in bringing ecological resilience into the boardroom may be the difference in time scales between corporate thinking and ecological time spans. Many companies work in rather short time scales (years or tens of years) as compared to high-latitude ecosystems that may require hundreds of years to recover (if they have enough resilience) from human-caused disturbance.

\section{Implications: The Pressing Need for a High-latitude Corpo- rate Research Agenda}

In this paper, we argue that the resilience of high-latitude regions depends, in part, on the actions of transnational and national companies. Such companies may directly impact the region through their daily operations, while others may have indirect impacts through their contribution to global processes such as climate change. While the resilience of high latitude regions is increasingly being strained, we suggest that the companies who bear some responsibility for this are more focused on ensuring social and economic resilience, perhaps at the expense of ecological resilience. That is, the feedback loop from these ecosystems and the boardroom may be weak in terms of ecological feedback but strong in terms of social and economic feedback loops. Yet, if ecosystem resilience may depend upon the effective functioning of feedbacks, a central question that emerges from our paper is how to ensure that high-latitude feedbacks and resilience enters the corporate boardroom in a meaningful way? 
A number of related questions emerge from our paper: First, what would happen if transnational and national companies operating in or impacting upon high-latitude regions began to manage for regional social-ecological resilience? Second, how can an expanded concept of organizational resilience, one that integrates ecological resilience, meaningfully enter into the boardrooms of key companies?

In order to answer these questions, we believe that it is necessary to identify which companies and other actors (Fig. 1) are involved in the region and to understand how these boardrooms are governed. We thus propose the need for a comprehensive audit to identify relevant corporate activity. This would include an analysis of corporate policies, programs, public relations strategies, and practices. In addition, it would be useful to identify other key actors such as the governments, international financing institutions, as key consumer segments, and civil society groups, which can help provide companies with important feedback. Next, an assessment of current corporate governance mechanisms is required and a plan for action needs to be developed. That is, what are the key corporate governance gaps by industry? What are the key mechanisms for effective governance? How can these be influenced? What government or EU policy options are available to encourage this process? And finally, how can we, as scholars, help make this happen?

\section{References and Notes}

Tavernise, S 2003. BP invest in Russian oil. International Herald Tribune, Feb 12, $\mathrm{http}: / /$ news.independent.co.uk/low res?story.jsp?story $=406609 \&$ host $=3 \&$ dir $=94$

3. Chapin, F.S., III, Peterson, G., Berkes, F., Callahan, T.V., Angelstam, P., Apps, M., Beier, C. and Bergeron, A.-S. et al. 2004. Resilience and Vulnerability of Northern Regions to Social and Environmental Change. Ambio 33, 344-349.

4. Folke, C., Carpenter, S., Elmqvist, T., Gunderson, L., Holling, C.S., Walker, B., Bengtsson, J. and Berkes, F. 2002. Resilience and sustainable development: Building adaptive capacity in a world of transformations. ICSU Series on Science for Sustainable Development 3, pp. 1-74

5. Holling, C.S. 1986. Resilience of ecosystems: Local surprise and global change. In: Sustainable Development and the Biosphere. Clark, W.C. and Munn, R.E. (eds) Sustainable Development and the Biosphere. Clark,

6. Chapin, F. S., III and Whiteman, G. 1998. Sustainable development of the boreal forest: Interaction of ecological, social, and business feedbacks. Conserv. Ecol. 2, (http://www.consecol.org/vol2/iss2/art12).

Chapin, F.S., III, Torn, M.S. and Tateno, M. 1996. Principles of ecosystem sustainability. Am. Nat. 148, 1016-1037.

8. Hart, S.L., Milstein, M.B., and Caggiano, J. 2003. Creating sustainable value: Executive commentary. Acad. Manage. Executive 2, 56.

. Nesmith, J. 2003. Global warming interferes with Alaska oil drilling. Seattle Post, Wednesday, July 23. http://seattlepi.nwsource.com/printer2/index. asp? ploc=b\&refer=http://seattlepi.nwsource.com/national/131906 oil23.html

10. Revkin, A.C. Looking for messes that are easy to fix. The New York Times; Nov. 18,2002, p. 20

11. Forbes, B., Fresco, N., Shvidenko, A., Danell, K. and Chapin, F.S., III. 2004. Geographic variations in anthropogenic drivers that influence the vulnerability and resilience of social-ecological systems. Ambio 33, 377-382.

12. Westley, F. 1995. Governing Design: The Management of Social Systems and Ecosystems Management. In: Barriers and Bridges to the Renewal of Ecosystems and Institutions. Gunderson, L.H., Holling, C.S. and Light, S.S. (eds). Columbia University Press, New York, pp. 391-427.

13. European Union. 2003. The Northern Dimensions Action Plan. (http://europa.eu.int/comm/external relations/north $\mathrm{dim} /$ )

14. http://www.ndep.org

15. http://www.stopesso.com/

16. http://www.ceaa.gc.ca/0009/0001/0001/0017/agreement_e.htm

7. http://www.menv.gouv.qc.ca/communiques_en/c20030228-eastmain.htm

8. http://news.nationalgeographic.com/news/2002/07/0702_020702_canadianrivers. htm

19. Weick, K.E. 1993. The collapse of sensemaking in organizations: The Mann Gulch disaster. Administrative Sci. Quarterly 38, 638-652.

20. Coutu, D.L. 2002. How resilience works. Harv. Business Rev. 5, 46-55.

21. http://www.bp.com/centres/press/s detail.asp?id=125

22. Freeman, S.F., Malz, M. and Hirschorn, L. 2003. Moral purpose and organizational resilience: Sandler, O-Neill \& Partners in the aftermath of September 11, 2001. In: Acad.Mgmt. Best Papers. D. Nagao (ed.). NY.

23. Shrivastava, P. 1994. CASTRATED environment: GREENING organizational studies. Organi. Studies 15, 705-726.

24. King, A. 1995. Avoiding ecological surprise: Lessons from long-standing communities. Acad. Manage. Rev. 20, 961-985.

25. Reed, D. 2002. Corporate governance reforms in developing countries. J. Business Ethics 3, 223-247.

26. Hellström, E. and Reunala, A. 1995. Forestry conflicts from the 1950's to 1983. European Forest Institute Research Report 3.

27. (http://www.asv.de/englisch/umwelt/frame.htm)

28. Forbes, B.C. 2004. Impacts of energy development in polar regions. In: Encyclopedia of Energy. Cleveland, C.J. (ed.). Academic Press, San Diego, pp. 93-105. dia of Energy. Cleveland, C.J. (ed.). Academic Pres.//www.bp.com/investor centre/index.asp\#

30. Driessen, P. 2002. BP: Beyond petroleum - or beyond probity?
29. http://www.cdfe.org/driessen.htm

31. Driessen, P. 2003. BP - back to petroleum. Review - Institute of public affairs 1, 13-14.

32. Cait Murphy, 2002. Is BP Beyond Petroleum? Hardly, Fortune, Sept. 16.

33. http://www.bp.com/environ_social/approach/global.asp

34. http://www.bp.com/centres/energy/chartingtool/

5. Gunderson, L.H. 2000. Ecological resilience-in theory and application. Annu. Rev. Ecol. Syst. 31, 425-439.

36. Jefferies, R.L. and Rockwell, R.F. 2002. Foraging geese, vegetation loss and soil degradation in an Arctic salt marsh. Appl. Veg. Sci. 5, 7-16.

37. Whiteman, G. 1999. Sustainability for the planet: a marketing perspective. Conserv. Ecol. 1, online (URL: http://www.consecol.org/vol3/iss1/art13)

Gail Whiteman is an assistant professor of Business Society Management at the Rotterdam School of Management, Erasmus University in The Netherlands. She is a specialist in business management with an extensive background in international development and civil society, and the environmental and social impacts of transnational corporations in the developing world. She has done previous research on ecological embeddedness, on the impact of the international mining sector, and also public policy research on the social and environmental impact of export credit agencies. Her PhD in Management is from Queens University, School of Business, in Canada. Her address: Department of Business-Society Management, Rotterdam School of Management, Erasmus University, PO Box 1738, 3000 DR Rotterdam, The Netherlands gwhiteman@fbk.eur.nl

Bruce C. Forbes has a background in applied ecology and geography in permafrost environments, his research encompasses both natural and social sciences. His experience is circumpolar having conducted field studies of human impacts on vegetation and soils, with special emphasis on the consequences of petroleum development, in the boreal and arctic ecosystems of Alaska, Canada, western and eastern Siberia, and Fennoscandia. Recent research has focused on management of arctic ungulates employing both western and local knowledge in cooperation with Nenets and Saami reindeer herders. His address: Arctic Centre, University of Lapland, FIN-96101 Rovaniemi, Finland. bforbes@ulapland.fi

Jari Niemelä is Dean of the Faculty of Biosciences and works at the Department of Biological and Environmental Sciences at the University of Helsinki. His research interests include conservation biology, biodiversity issues and urban ecology. His address: Department of Biological and Environmental Sciences, Faculty of Biosciences P.O. Box 65 FIN00014 University of Helsinki, Finland jari.niemela@helsinki.fi

F. Stuart Chapin, III is an ecosystem ecologist who studies the impacts of global change on arctic and boreal ecosystems. His current research emphasizes the resilience of social-ecological systems at high latitudes, particularly recent changes in human-fire interactions. He directs the Bonanza Creek Long-Term Ecological Research (LTER) program and the graduate program in Resilience and Adaptation. His address: Institute of Arctic Biology, University of Alaska, Fairbanks, AK 99775, USA. terry.chapin@uaf.edu 